\title{
STRATEGY ANALYSIS AND CHOICE
}

\author{
Branislav Djordjević \\ Emeritus, “Union” University, Belgrade, Serbia
}

\section{(C) MESTE NGO}

JEL category: L1, R3

\section{Life is full of lousy options. Peter Drucker}

\begin{abstract}
Strategy analysis and choice seek to determine alternative courses of action that could best enable the firm to achieve its mission and objectives. They involve subjective decisions making based on the objective information. This article focuses on generating and evaluating alternative strategies, as well as selecting strategies to pursue. It introduces concepts that can help strategists generate feasible alternatives, evaluate those alternatives, and choose a specific course of action. Behavioral aspects of strategy formulation are described, including politics, culture, ethics, and social responsibility considerations. Modern tools for formulating strategies are described, and appropriate role of a board of directors is discussed. Special attention is paid to the process of generating and selecting strategies including a comprehensive strategy-formulation framework, as well as the cultural aspect and the politics of strategy choice.
\end{abstract}

Keywords: strategy, analysis, mission, cultural aspects, politics of strategy choice, governance

\section{THE NATURE OF STRATEGY ANALYSIS AND CHOICE}

This article focuses on generating and evaluating alternative strategies, as well as selecting strategies to pursue. Strategy analysis and choice seek to determine alternative courses of action that could best enable the firm to achieve its mission and objectives. The firm's present strategies, objectives, and mission, coupled with the external and internal audit information, provide a basis for generating and evaluating feasible alternative strategies.

Address of the author:

Branislav Đorđević

莑三” brankonis@live.com
Unless a desperate situation confronts the firm, alternative strategies will likely represent incremental steps that move the firm its present position to a desired future position. Alternative strategies do not come out of the wild blue bounder; they are derived from the firm's vision, mission, objectives, external audit, and internal audit; they are consistent with, or build on, past strategies that have worked well. Note from the "Natural Environment Perspective" box that the strategies of both companies and countries are increasingly scrutinized and evaluated from a natural environment perspective. Companies such as Wal-Mart now monitor not only the price its vendors offer for products, but also how those products are made in terms of environmental practices. A growing number of business schools offer separate courses and even a concentration 
in environmental management or sustainability, the idea that a business can meet its financial goals without hurting the environment.

\section{THE PROCESS OF GENERATING AND SELECTING STRATEGIES}

Strategies never consider feasible alternatives that could benefit the firm because there are an infinite number of possible actions and an infinite number of ways to implement those actions. Therefore, a manageable set of the most attractive alternative strategies must be developed. The advantages, disadvantages, trade-offs, cists, and benefits of these strategies should be determined. This section discusses the process that many firms use to determine an appropriate set of alternative strategies.

Identifying and evaluating alternative strategies should involve many of the managers and employees who earlier assembled the organizational vision and mission statements, performed the external audit, and conducted the internal audit. Representatives from each department and division of the firm should be included in this process, as was the case in previous strategy-formulation activities. Recall that involvement provides the best opportunity for managers and employees to gain an understanding of what the firm is doing and why and to become committed to helping the firm accomplish its objectives.
All participants in the strategy analysis and choice activity should have the firm's external and internal audit information by their sides. This information, coupled with the firm's mission statement, will help participants crystallize in their own minds particular strategies that they believe could benefit the firm most. Creativity should be encouraged in this thought process.

Alternative strategies proposed by participants should be considered and discussed in a meetings or series of meetings. Proposed strategies should be listed in writing. When all feasible strategies identified by participants are given and understood, the strategies should be ranked in order of attractiveness by all participants, with 1 = should not be implemented, $2=$ possibly should be implemented, $3=$ probably should be implemented, and $4=$ definitely should be implemented. This process will result in a prioritized list of best strategies that reflect the collective wisdom of the group.

\subsection{A Comprehensive Strategy- Formulation Framework}

Important strategy-formulation techniques can be integrated into a three-stage decision-making framework, as shown in Table 1. The tools presented in this framework are applicable to all size and types of organizations and can help strategists identify, evaluate and select strategies.

Table 1. Matching key external and internal factors to formulate alternative strategy

\begin{tabular}{|lll|}
\hline Key internal factor & Key external factor & Resultant strategy \\
\hline $\begin{array}{l}\text { Excess working capacity (an } \\
\text { internal strength) }\end{array}$ & $\begin{array}{l}\text { 20 percent annual growth in } \\
\text { the cell phone industry (an } \\
\text { external opportunity) }\end{array}$ & $=$ Acquire Cellophane, Inc. \\
\hline $\begin{array}{l}\text { Insufficient capacity (an } \\
\text { internal weakness) }\end{array}$ & $\begin{array}{l}\text { Exit of two major foreign } \\
\text { competitors from the industry } \\
\text { (an external opportunity) }\end{array}$ & $=\begin{array}{l}\text { Pursue horizontal integration } \\
\text { by buying computer factory }\end{array}$ \\
\hline $\begin{array}{l}\text { Strong R\&D expertise (an } \\
\text { internal strength) }\end{array}$ & $\begin{array}{l}\text { Decreasing numbers of } \\
\text { younger adults (an external } \\
\text { threat) }\end{array}$ & $=\begin{array}{l}\text { Develop new products for } \\
\text { older adults }\end{array}$ \\
\hline $\begin{array}{l}\text { Poor employee morale (an } \\
\text { internal weakness) }\end{array}$ & $\begin{array}{l}\text { Strong union activity (an } \\
\text { external threat) }\end{array}$ & $\begin{array}{l}\text { Develop a new employee } \\
\text { benefits package }\end{array}$ \\
\hline
\end{tabular}


Stage 1, of the formulation framework consists of the EFE Matrix, the IFE Matrix, and the Competitive Profile Matrix (CPM). Called the Input Stage, Stage 1 summarizes the basic input information needed to formulate strategies. Stage 2, called the Matching Stage focuses upon generating feasible alternative strategies by aligning key external and internal factors. Stage 2 techniques include the Strengths-WeaknessesOpportunities-Threats (SWOT) Matrix, the Strategic Position and Action Evaluating (SPACE) Matrix, the Boston Consulting group (BCG) Matrix, the Internal-External (IE) Matrix, and Grand Strategy Matrix. Stage 3, called the Decision Stage, involve a single technique, the Quantitative Strategic Planning Matrix (QSPM). A QSPM uses input information from Stage 1 to objectively evaluate feasible alternative strategies identified in Stage 2. A QSPM reveals the relative attractiveness of alternative strategies and thus provides objective basis for selecting specific strategies.

All nine techniques included in the strategyformulation framework require the integration of intuition and analysis. Autonomous divisions in an organization commonly use strategy-formulation techniques to develop strategies and objectives. Divisional analyses provide a basic for identifying, evaluating, and selecting among alternative corporate-level strategies. Strategists themselves, not analytic tools, are always responsible and accountable for strategic decisions. Lenz emphasized that the shift from a words-oriented to a numbers-oriented planning process can give rise to a false sense of certainty, it can reduce dialogue, discussion, and argument as a means for exploring understandings, testing assumption and fostering organizational learning. (Lenz, 1987) Strategists, therefore, must be wary of this possibility and use analytical tools to facilitate, rather than to diminish, communication. Without objective information and analysis, personal biases, politics, emotions, personalities, and hallo error (the tendency to put too much weight on a single factor) unfortunately may play a dominant role in the strategy-formulation process.

\subsection{The Input Stage}

The input tools require strategists to quantify subjectivity during early stages of the strategyformulation process. Making small decisions in the input matrices regarding the relative importance of external and internal factors allows strategists to more effectively generate and evaluate alternative strategies. Good intuitive judgment is always needed in determining appropriate weights and ratings.

\subsection{The Matching Stage}

Strategy is sometimes defined as the match an organization makes between its internal resources and skills and opportunities and risks created by its external factors. (Grant, 1991) The matching stage of the strategy-formulation framework consists of five techniques that can be used in any sequence: the SWOT matrix, the SPACEMatrix, the BCG matrix, the IE Matrix, and in the Grand Strategy.

Table 2 Matching key external and internal factors to formulate alternative strategy

\begin{tabular}{|l|l|l|}
\hline Key Internal Factor & Key External Factor & Resultant Strategy \\
\hline $\begin{array}{l}\text { Excess working capacity (an } \\
\text { internal strength) }\end{array}$ & $\begin{array}{l}\text { 20 percent annual growth in } \\
\text { the cell phone industry (an } \\
\text { external opportunity) }\end{array}$ & Acquire Cellphone, Inc. \\
\hline $\begin{array}{l}\text { Insufficient capacity (an } \\
\text { internal weakness) }\end{array}$ & $\begin{array}{l}\text { Exit of two major foreign } \\
\text { competitors from the industry } \\
\text { (an external opportunity) }\end{array}$ & $\begin{array}{l}\text { Pursue horizontal integration } \\
\text { by buying computer factory }\end{array}$ \\
\hline $\begin{array}{l}\text { Strong R\&D expertise (an } \\
\text { internal strength) }\end{array}$ & $\begin{array}{l}\text { Decreasing numbers of } \\
\text { younger adults (an external } \\
\text { threat) }\end{array}$ & $\begin{array}{l}\text { Develop new products for } \\
\text { older adults }\end{array}$ \\
\hline $\begin{array}{l}\text { Poor employee morale (an } \\
\text { internal weakness) }\end{array}$ & $\begin{array}{l}\text { Strong union activity (an } \\
\text { external threat) }\end{array}$ & $\begin{array}{l}\text { Develop a new employee } \\
\text { benefits package }\end{array}$ \\
\hline
\end{tabular}


These tools rely upon information derived from the input stage to much external opportunities and threats with internal strengths and weaknesses. Matching external and internal critical success factors is the key to effectively generating feasible alternative strategies. For example, a firm with excess working capital (an internal strength) could take advantage of the cell phone industry's 20 percent annual growth rate (an external opportunity) by acquiring Cellphone, Inc., a firm in the cell phone industry. This example portrays simple one-to-one matching. In most situations, external and internal relationships are more complex, and the matching requires multiple alignments for each strategy generated. The basic concept of matching is illustrated in Table 2.

\section{CULTURAL ASPECT OF STRATEGY CHOICE}

All organizations have a culture. Culture includes the set of shared values, beliefs, attitudes, customs, norms, personalities, heroes, and heroines that describe a firm. Culture is the unique way an organization does business. It is the human dimension that creates solidarity and meaning, and it inspires commitment and productivity in an organization when strategy changes are made. All human beings have a basic need to make sense of the world, to feel in control, and make meaning. When events threaten meaning, individuals react defensively. Managers and employees may even sabotage new strategies in an effort to recapture the status quo.

It is beneficial to view strategic management from a cultural perspective because success often rests upon the degree of support that strategies receive from a firm's culture. If a firm's strategies are supported by cultural products such as values, beliefs, rites, rituals, ceremonies, stories, symbols, language, heroes, and heroines, then managers often can implement changes swiftly and easily. However, if a supportive culture does not exist and is not cultivated, then strategy change may be ineffective or even counterproductive. A firm's culture can become antagonistic to new strategies, and the result of that antagonism may be confusion and disarray.

Strategies that require fewer cultural changes may be more attractive because extensive changes can take considerable time and effort. Whenever two firms merge, it becomes especially important to evaluate and consider culture-strategy linkages.

Culture provides an explanation for the difficulties a firm encounters when it attempts to shift its strategic direction, as the following statement explains:

Not only has the "right" corporate culture become the essence and foundation of corporate excellence, but success or failure of needed corporate reforms hinges on management's sagacity and ability to change the firm's driving culture in time and in tune with required changes in strategies. (Allarie \& Firsirotu, 1985) Another excellent article is "Integrating Strategy formulation with organizational Culture" (Shrivastava, 1985).

\section{THE POLITICS OF STRATEGY CHOICE}

All organizations are political. Unless managed, political maneuvering consumes valuable time, and subverts organizational objectives, diverts human energy, and results in the loss of some valuable employees. Sometimes political biases and personal preferences get unduly embedded in strategy choice decisions. Internal politics affect the choice of strategies in all organizations. The hierarchy of command in an organization, combined with the career aspirations of different people and the need to allocate scarce resources, guarantees the formation of coalitions of individuals who strive to take care of themselves first and the organization second third, or fourth. Coalitions of individuals often form around key strategy issues that face an enterprise. A major responsibility of strategists is to gain the support of key individuals and groups of individuals.

In the absence of objective analyses, strategy decisions too often are based on the politics of the moment. With development of improved strategyformation tools, political factors sometimes dictate strategies, and this is unfortunate. Managing political relationships is an integral part of building enthusiasm and esprit de corps in an organization.

A classic study of strategic management in nine large corporations examined the political tactics of successful and proposals strategists. (Quinn, 
1980) These political tactics are listed in the Thompson and Strickland's "Strategic Management: Concepts and Cases) (1984).

Successful strategists were found to let weekly supported ideas and proposals die through inaction and to establish additional hurdles or tests for strongly supported ideas considered unacceptable but not openly opposed. Successful strategists kept a low political profile on unacceptable proposals and strived to let most negative decisions come from subordinates or a group consensus, thereby reserving their personal vetoes for big issues and crucial movements. Successful strategists did a lot of chatting and informal questioning to stay abreast of how things were progressing and to know when to intervene. They led strategy on informal questioning, and sought to probe and clarify until a consensus emerged.

Successful strategies generously and visibly rewarded key trusts that succeeded. They assigned responsibility for major new thrusts to champions, the individuals most strongly identified with idea or product and whose futures were linked to its success. They stayed alert to the symbolic impact of their own action and statements so as not to send false signals that could stimulate movements in unwanted directions.

Successful strategies ensured that all major power bases within an organization were represented in, or had access to, top management. They interjected new faces and new views into considerations of major changes. This is important because new employees and managers generally have more enthusiasm and drive than employees who have been with the firm a long time. New employees do not see the world the same old way; nor do they act as screens against changes. Successful strategists minimized their own political exposure on highly controversial issues and in circumstances in which major opposition from key power centers was likely. In combination, these findings provide a basis for managing political relationships in an organization.

Because strategies must be effective in achievements on the marketplace and capable of gaining internal commitment, the following tactics used by politicians for centuries can aid strategists:
- Equality - It is often possible to achieve similar results using different means or paths. Strategists should recognize that achieving a successful outcome is more important than imposing the method of achieving it. It may be possible to generate new alternatives that give equal results but with far greater potential for gaining commitment.

- Satisfying - Achieving satisfactory results with an acceptable strategy far better than failing to achieve optimal results with an unpopular strategy.

- Generalization - Shifting focus from specific issues to more general ones may increase strategists' options for gaining organizational comment.

- Focus on Higher - Order Issues - By raising an issue to a higher level, many short-term interests can be postponed in favor of longterm interests. For instance, by focusing on issues of survival, the airline and automotive industries were able to persuade unions to make concessions on wage increases.

- Provide political Access on Important Issues -Strategy and policy decisions with significant negative consequences for middle managers will motivate intervention behavior from them. If middle managers do not have an opportunity to take a position on such decisions in appropriate political forums, they are capable of successfully resisting the decisions after they are made. Providing such political access provides strategists with information that otherwise might not be available and that could be useful in managing intervention behavior. (Guth \& MacMillan, 1986)

\section{GOVERNANCE ISSUES}

A "director" according to Webster's dictionary is "one of a group of persons entrusted with the overall direction of corporate enterprise." A bound of directories is a group of individuals who are elected by ownership of a corporation to have oversight and guidance over management and who look out for shareholders' interests. The act of oversight and direction is referred to as governance. The National Association of 
Corporate Directors defines governance as "the characteristic of ensuring that long-term strategic objectives and plans are established and that the proper management structure is in place to achieve those objectives, while at the same time making sure that the structure functions to maintain the corporation's integrity, reputation, and responsibility to its various constituencies." This broad scope of responsibility for the board shows how boards are being held accountable for the entire performance of the firm. In the Worlcom, Tyco, and Enron bankruptcies and scandals, the firm's board of directors were sued by shareholders for mismanaging their interests. New accounting rules in the United States and Europe now enhance cooperate-governance codes and require much more extensive financial disclosure among publicity held firms. The role and duties of a board of directors can be divided into four broad categories, as indicated in Table 3.

Table 3 Board of Director Duties and Responsibilities

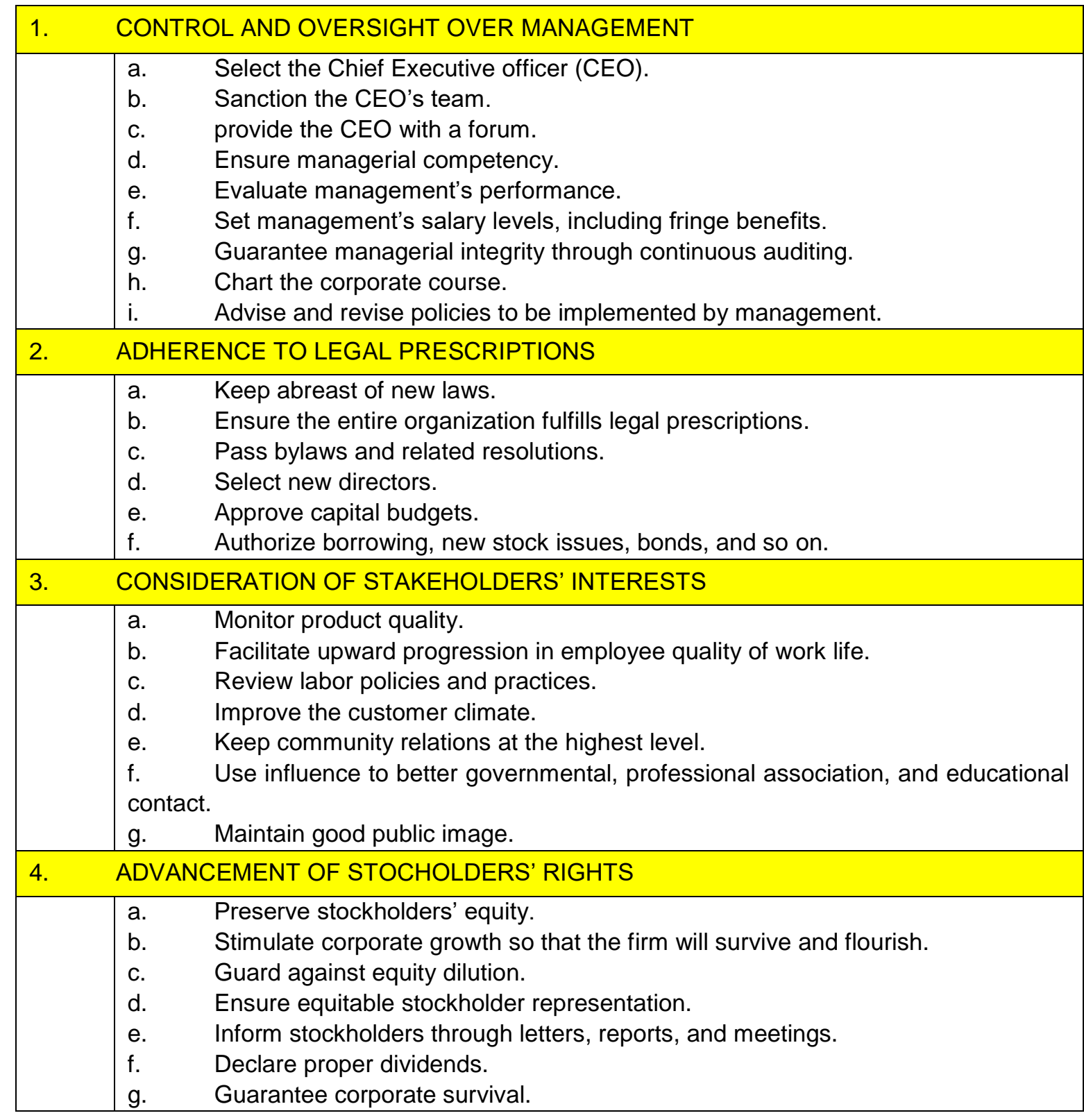


Until recently, boards of directors did most of their work sitting around polished wooden tables. However, Hewlett-Packard's directors, among many others, now log on to their own board Web site twice a week and conduct business based on extensive confidential briefing information posted there by the firm's top management team. Then the board members meet face to face and fully informed every two months to discuss the highest issues facing the firm. Even the decision of whether to locate corporations in countries with low tax rates would be reviewed by a board of directors.

Today, boards of directors are composed mostly of outsiders who are becoming more involved in organizations' strategic management. The trend in the United States, for example, is toward much greater board member accountability with smaller boards, now averaging 12 members rather than 18 as they did a few years ago. BusinessWeek magazine recently evaluated the boards of the largest U.S. companies and provided the following "principles of good governance":

1. No more than two directors are current or former company executives.

2. No directors do business with the company or accept consulting or legal fees from the firm.

3. The audit, compensation, and nominating committees are made up solely of outside directors.

4. Each director owns a large equity stake in the company, excluding stock options.

5. At least one outside director has extensive experience in the company's core business and at least one has been CEO of an equivalent-size company.

6. Fully employed directors sit on no more than four boards and retirees sit no more than seven.

7. Each director attends at least 75 percent of all meetings.

8. The board meets regularly without management present and evaluates its own performance annually.

9. The audit committee meets at least four times a year.

10. The board is frugal on executive pay, diligent in CEO succession oversight responsibilities, and prompt to act when trouble arises.
11. The CEO is not also the chairperson of the board.

12. Shareholders have considerable power and information to choose and replace directors.

13. Stock options are considered a corporate expense.

14. There are no interlocking directorships (where a director or CEO sits on another director's board). (Lavelle, 2002)

Just as directors are beginning to place more emphasis on staying informed about an organization's health and operations, they are also taking a more active role in ensuring that publicly issued documents are accurate representations of a firm's status. It is becoming widely recognized that a board of directors has legal responsibilities to stock-holders and society for all company activities, for corporate performance, and for ensuring that a firm has an effective strategy. Failure to accept responsibility for auditing or evaluating a firm's strategy is considered a serious breach of a director's duties. Stockholders, government agencies, and customers are filling legal suits against directors for fraud, omissions, inaccurate disclosures, lack of due diligence, and culpable ignorance about a firm's operations with increasing frequency. Liability insurance for directors has become exceptionally expensive and has caused numerous directors to resign.

More than 50 percent of outside directors at Fortune 500 firms have quit in recent years. (Fisher, 2005) A direct response of increased pressure on directors to stay informed and execute their responsibilities is that audit committees are becoming commonplace. A bound of directors should conduct an annual strategy audit in much the same fashion that it reviews the annual financial audit. In performing such an audit, a board could work jointly with operating management and/or seek outside counsel. Boards should play a role beyond that of performing a strategic audit. They should provide greater input and advice in the strategy-formulation process to ensure that strategists are providing for the longterm needs of the firm. This is being done through the formation of three particular board committees: nominating committees to evaluate the performance of top executives and determine the terms and conditions of their employment; and audit committees to give board-level attention to 
company according and financial policies and performance.

\section{CONCLUSION}

The essence of strategy formulation is an assessment of whether an organization is doing the right things and how it can be more effective in what it does. Every organization should be wary of becoming a prisoner of its own strategy, because even the best strategies become obsolete sooner or later. Regular reappraisal of strategy helps management avoid complacency. Objectives and strategies should be consciously developed and coordinated and should not merely evolve out of day-to-day operating decisions.
An organization with no sense of direction and no coherent strategy precipitates its own demise. When an organization does not know where it wants to go it usually ends up some place it does want to be. Every organization needs to consciously establish and communicate clear objectives and strategies.

Behavioral, cultural and political aspects of strategy generation and selection are always important to consider and manage. Because of increased legal pressure from outside groups, boards of directors are assuming a more active role in strategy analysis and choice. This is a positive trend for organizations.

\section{WORKS CITED}

Allarie, Y., \& Firsirotu, M. (1985, Spring). How to Implement Radical Strategies in Large Organizations. Sloan Management Review, 26(3), 19.

Fisher, A. (2005). Board Seats Are going Begging. Fortune.

Grant, R. (1991, Spring). The Resource-Based Theory of Competitive Advantage: Implications for Strategy Formulation. California Management Review, 114.

Guth, W., \& MacMillan, I. (1986, Jul-Aug ). Strategy Implementation Versus Middle Managment SelfInterest. Strategic Management Journal, 7(4), 321.

Lavelle, L. (2002, Oct 7). The Best and Worst Boards. Business Week, 104-110.

Lenz, R. (1987, Jan-Feb). Managing the Evolution of the strategic Planning Process. Business Horizons, $30(1), 37$.

Quinn, J. B. (1980). Strategies for Changes: Logical Instrumentalism. (R. D. Irwin, Ed.) Homewood, II.

Shrivastava, P. (1985, Winter). Integrating Strategy formulation with organizational Culture. Journal of Business Strategy, 5(3), 103-111.

Thompson, A., \& Strickland, A. (1984). Strategic Management: Concepts and Cases. Piano, TX: Business Publications.

Received for publication:

Revision received:

Accepted for publication:
23.03.2014

15.04 .2014

02.07.2014

\section{How to cite this article?}

Style - APA Sixth Edition:

Djordjević, B. (2014, 07 15). Strategy analysis and choice. (Z. Čekerevac, Ed.) MEST Journal, 2(2), $42-$ 50. doi:10.12709/mest.02.02.02.05

Style - Chicago Fifteenth Edition:

Djordjević, Branislav. 2014. "Strategy analysis and choice." Edited by Zoran Čekerevac. MEST Journal (MESTE) 2 (2): 42-50. doi:10.12709/mest.02.02.02.05. 
Style - GOST Name Sort:

Djordjević Branislav Strategy analysis and choice [Journal] // MEST Journal / ed. Čekerevac Zoran. Belgrade : MESTE, 07 15, 2014. - 2 : Vol. 2. - pp. 42-50.

Style - Harvard Anglia:

Djordjević, B., 2014. Strategy analysis and choice. MEST Journal, 15 07, 2(2), pp. 42-50.

Style - ISO 690 Numerical Reference:

Strategy analysis and choice. Djordjević, Branislav. [ed.] Zoran Čekerevac. 2, Belgrade : MESTE, 07 15, 2014, MEST Journal, Vol. 2, pp. 42-50. 